\title{
Quality of life of victims of traumatic brain injuries un- dergoing neurosurgery
}

Qualidade de vida das vítimas de trauma cranioencefálico submetidas a neurocirurgias Calidad de vida de las víctimas de traumatismo craneoencefálico sometidas a neurocirugías

Ana Carolina Bezerra de Lima*iD; Cristine Vieira do Bonfim**iD; Adriana Conrado de Almeida***iD;

Fernando Ramos Gonçalves**** (D); Betise Mery Alencar Sousa Macau Furtado***** (DD

\section{Abstract}

Background: The improvements occurred in trauma care reflected in the increase of survivors of traumatic brain injury (TBI). However, the deficiencies and disabilities have not reduced. The quality of life (QOL) has been recognized as an essential result to quantify the subjective burden of TBI in survivors.

Objective: To assess the QOL of TBI victims undergoing neurosurgeries in a hospital of reference.

Methodology: A cross-sectional study conducted with 116 TBI victims treated in a neurosurgery outpatient clinic. The data were obtained from medical records and using the application of the questionnaire World Health Organization Quality of Life - Bref.

Results: The QOL of participants was above the average (60.02). The lowest mean was the physical domain (42.33). People who studied and/or worked obtained higher scores for the physical $(p=0.027)$ and psychological $(p=0.052)$ domains. Conclusion: Living with someone, studying, and working are factors that interfere with the perception of a better QOL. The elderly showed a tendency to a worse assessment of post-trauma-related QOL.

Keywords: quality of life; brain injuries, traumatic; rehabilitation; nursing assessment; wounds and injuries

\section{Resumo}

Enquadramento: As melhorias ocorridas no atendimento ao trauma repercutiram-se no aumento de sobreviventes de traumatismo cranioencefálico (TCE). Todavia, as deficiências e incapacidades não reduziram. A qualidade de vida $(\mathrm{QV})$ foi reconhecida como um resultado essencial para quantificar a carga subjetiva do TCE em sobreviventes. Objetivo: Avaliar a QV das vítimas de TCE submetidas a neurocirurgias em hospital de referência.

Metodologia: Estudo transversal, realizado com 116 vítimas de TCE acompanhadas em ambulatório de neurocirurgia. Os dados foram obtidos a partir dos prontuários e por meio da aplicação do questionário World Health Organization Quality of life - Bref.

Resultados: A QV dos participantes esteve acima da média $(60,02)$. A menor média foi a do domínio físico $(42,33)$. Pessoas que estudavam e/ou trabalhavam obtiveram scores maiores para os domínios físico $(p=0,027)$ e psicológico $(p=0,052)$. Conclusão: Morar com alguém, estudar, trabalhar são fatores que interferem na perceção de uma melhor QV. Os idosos mostraram tendência a uma pior avaliaçáo da QV relacionada com o pós-trauma.

Palavras-chave: qualidade de vida; lesôes encefálicas traumáticas; reabilitação; avaliação em enfermagem; ferimentos e lesóes

*BSc., Resident Nurse, Hospital da Restauração, 50070-025, Recife, Pernambuco, Brasil [lima.carolinab11@gmail.com]._D https://orcid.org/0000-0003-3110-2117.Contribution to the article: project elaboration; bibliographical research; data collection; statistical treatment and assessment; data analysis and discussion.

**Ph.D., Sanitarian, Researcher of Fundação Joaquim Nabuco, 52061-080, Recife, Pernambuco, Brasil [ cristine.bonfim@uol.com.br].(1) https://orcid.org/0000-0002-4495-9673.Contribution to the article: statistical treatment and assessment, and data analysis and discussion. ***:Ph.D., NR, Adjunct Professor, University of Pernambuco, 50100-010, Recife, Pernambuco, Brasil [aconradoalmeida@yahoo.com.br]. (D) https://orcid.org/0000-0001-6141-0458. Contribution to the article: substantial contribution to the data analysis and discussion.

*****Msc., NR, Assistant Professor, University of Pernambuco, 50100-010, Recife, Pernambuco, Brasil [ fernandoramos30@uol.com.br].(D) https://orcid.org/0000-0003-2692-9769. Contribution to the article: data analysis and discussion.

******:Ph.D., NR, Adjunct Professor of University of Pernambuco, 50100-010, Recife, Pernambuco, Brasil [betisemery@gmail.com].(1) https://orcid.org/0000-0001-6344-8257.Contribution to the article: project elaboration; bibliographical research; guidance in data collection; statistical treatment and assessment, data analysis and discussion, writing of the article. Address for correspondence: Avenida Boa Viagem, 234, Apto 701, Pina, Recife, PE, Brasil, CEP 51011000.

\section{Resumen}

Marco contextual: Las mejoras que han tenido lugar en la atención al traumatismo han repercutido en el aumento de supervivientes al traumatismo craneoencefálico (TCE). No obstante, las deficiencias y discapacidades no se redujeron. La calidad de vida $(\mathrm{QV}$, por sus siglas en portugués) se ha reconocido como un resultado esencial para medir la carga subjetiva del TCE en supervivientes.

Objetivo: Evaluar la QV de las víctimas de TCE sometidas a neurocirugías en un hospital de referencia.

Metodología: Estudio transversal, realizado con 116 víctimas de TCE acompañadas en un ambulatorio de neurocirugía. Los datos se obtuvieron a partir de los registros y por medio de la aplicación del cuestionario World Health Organization Quality of life - Bref.

Resultados: La QV de los participantes se situó por encima de la media $(60,02)$. La media más baja fue la relativa al dominio físico $(42,33)$. Las personas que estudiaban y/o trabajaban obtuvieron una puntuación más alta para los dominios físico $(p=0,027)$ y psicológico $(p=0,052)$.

Conclusión: Vivir con alguien, estudiar y trabajar son factores que interfieren en la percepción de una mejor QV. Los ancianos muestran una tendencia a una peor evaluación de la QV relacionada con el postrauma.

Palabras clave: calidad de vida; lesiones traumáticas del encéfalo; rehabilitación; evaluación en enfermería; heridas y lesiones 


\section{Introduction}

Presently, traumatic brain injury (TBI) is one of the leading causes of death and long-term disability, particularly in young adults in full productive stage (Scholten et al., 2015). This kind of injury has important physical, cognitive, and behavioral repercussions in the life of the victim besides the acute phase of the event, which can result in deficiencies and disabilities and interfere in the family and social context (Vieira, Hora, Oliveira, Ribeiro, \& Sousa, 2013).

There is an estimated incidence of approximately 10 million people around the world. In the United States, 1.17 million people each year are admitted to an emergency department due to brain traumas, which occupy the third position of injury-related deaths. In Europe, there is a rate of overall incidence of 262 cases per 100 thousand individuals, whose most frequent causes are falls and traffic accidents (Blennow et al., 2016; Peeters et al., 2015). In Brazil, there was, between 2008 and 2012, an annual incidence of 65.7 admissions per 100 thousand inhabitants, with a mortality rate of $7.7 \%$, and age group of 20 to 29 years with the largest number of hospital deaths (Almeida et al., 2016).

Quality of life (QOL) has been recognized as an essential result to quantify the subjective burden of TBI in survivors (Scholten et al., 2015). Therefore, it is important to obtain more information on the measurement of the QOL of patients with $\mathrm{TBI}$, since there is a great need to document their recovery paths and to quantify the impact of TBI on the health of the population over time, which justifies the conduction of this research. The objective of this study is, then, to assess the QOL of TBI victims undergoing neurosurgery in a hospital of reference.

\section{Background}

TBI is an injury that causes changes in the brain, meninges, encephalon, or intracranial vessels, and may temporarily or permanently cause cognitive or functional impairment. The care approach will depend on the severity of the TBI, and the criteria for surgical indication include location, size, and volume of the injury, associated injuries, and neurological scenario (Blennow et al., 2016).

A high proportion of survivors of severe TBI requires prolonged rehabilitation and can suffer physical, cognitive, and psychological long-term disorders, which can dramatically reduce the QOL. On the other hand, some chronic consequences, for instance, the post-concussion syndrome and chronic traumatic encephalopathy, were also identified in a proportion of cases previously classified as moderate or minor (Vieira et al., 2013). Regardless of the injury's severity, this burden affects the everyday life of survivors and their families and also has significant social and economic costs (Ruet et al., 2017). Regarding this scenario, TBI is a serious public health problem and has significant economic and social impacts and striking consequences in QOL (Almeida et al., 2016).

The World Health Organization (WHO) defines quality of life as being

the individual's perception about their position in life, in the cultural context, and in the system of values in which they live, and in relation to their goals, expectations, standards, and complications, taking into account the physical, social, and psychological dimensions of the individual, as well as their relationship with the environment. (WHO, 1997, p. 3)

The United Nations (UN), through the United Nations Development Program (UNDP), highlights the QOL as one of the Millennium Development Goals (MDGs), which implies its promotion in health scenarios (Rodrigues et al., 2015).

The major improvements occurred in trauma care reflected in the increase of the number of survivors of TBI; however the deficiencies and disabilities have not reduced (Sinha, Gunawat, Nehra, \& Sharma, 2013).

\section{Research Question}

What is the QOL of TBI victims undergoing neurosurgery in a tertiary hospital of reference, from the perspective of the patients themselves?

\section{Methodology}

This was a cross-sectional study, developed in the Hospital da Restauração Governador Paulo 
Guerra (HR), which is located in Recife (PE), Brazil. The HR is a teaching hospital of high complexity, a reference in emergencies and traumas, which performs an average of 700 monthly surgeries and approximately 12,300 outpatient visits. Its main characteristic is the care to trauma patients, predominantly neurosurgery and brain injury.

The study population was composed of victims of TBI accompanied in the outpatient clinic of neurosurgery of the HR, with 18 years or more years of age, undergoing neurosurgeries. The sample was non-probabilistic, consecutive, among patients who attended the previously scheduled appointment, totalling 116 persons. Sociodemographic data were obtained through a questionnaire developed for exclusive use in this research, whose controlled variables were: sex, age, skin color/race, origin, religion, marital status, education, social adjustment, and wage income. For the socio-economic division, the Criterion of Economic Classification of Brazil (the Brazilian Association of Research Companies) was considered based on the average family income. Clinical data were obtained between September 2016 and February 2017, based on the analysis of medical records of selected patients and the severity of the trauma through the Glasgow Coma Scale (GCS), in which the best response of the patient is considered, and the sum of scores classifies the TBI as minor (GCS = 13-15), moderate (GCS = 9-12), or severe (GCS =3-8; Oliveira, Pereira, \& Freitas, 2014).

The instrument used to assess the QOL of participants was the World Health Organization Quality of Life - Bref (WHOQOL-Bref), a suitable tool for the assessment of QOL of TBI victims due to good internal consistency and test-retest reliability (Oliveira et al., 2014). This instrument is an abbreviation of the WHOQOL-100, a questionnaire with 100 questions, developed by the WHOQOL Group from a cross-cultural perspective for international use. The WHOQOL-Bref was adapted and validated for the Brazilian population (Fleck et al., 2000) and is organized in 26 questions that include two general questions of QOL (perception of quality of life and satisfaction with health) and 24 specific questions of physical (pain and discomfort, energy and fatigue, sleep and rest, mobility, life activities, dependence on medication or treatments, working ability), psychological (positive feelings, thinking, learning, memory and concentration, self-esteem, body image and appearance, negative feelings, spirituality/religion/personal beliefs), social relations (personal relationships, social support, sexual activity), and environment (physical safety and protection, home environment, financial resources, health and social care, opportunity to acquire new information and skills, opportunities for recreation and leisure) domains.

The answers follow a Likert-type scale, whose values from 1 to 5 indicate: the higher the score, the better the QOL. Subsequently, the values of these responses are converted to a percentile scale, where the closer to 100 , the better the QOL.

The collected data were stored in electronic platforms to be analyzed later in the program R-3.3.3 for Windows. Pearson's correlation coefficient was used to verify the intensity of linear association that exists between the scores of the dimensions of the WHOQOL (domains and questions about general QOL) and the quantitative variables. This coefficient measures the linear correlation between two quantitative variables and can assume values between 0 and 1 , which can be both positive and negative. A commonly used classification for these correlation values consists of: (i) too low, for values between 0 and 0.1 , (ii) low, for values between 0.1 and 0.3 , (iii) moderate, for correlation between 0.3 and 0.5, (iv) high, between 0.5 and 0.7, (v) too high, between 0.7 and 0.9, and (vi) almost perfect, between 0.9 and 1 (Hinkle, Wiersma, \& Jurs, 1998).

Regarding the qualitative variables that describe the sociodemographic characteristics of the population, this study used the non-parametric Mann-Whitney $U$-test to identify differences between its categories and the scores of the WHOQOL-Bref. The recommended test for this type of research is the $t$-test for the comparison of means. However, this was not possible, because one of its assumptions was not met, which is the normality of the sample data. To verify the non-normality, this research used the Kolmogorov-Smirnov test (Contador \& Senne, 2016), observing the maximum absolute difference between the normal and the empirical role of data.

The Cronbach's alpha coefficient was calculated to assess the internal consistency of the WHOQOL-Bref questionnaire. This coefficient varies 
between 0 and 1 , being that the closer to 1 , the greater the internal consistency. As a general rule, the authors recommend alpha values greater than 0.8 . However, values above 0.6 already indicate satisfactory results (Cárdenas \& Pons, 2012). This study used a confidence level of $95 \%$, therefore, for statistically significant values one of the criteria adopted was scientific evidence that corroborates the results with a $p$-value of less than 0.05 . The study was approved by the Ethics and Research Committee of the HR (Opinion no. 1,639,312) and received the consent of the institution, as well as the signing of free and informed consent of the patients.

\section{Results}

Of the 116 study participants, 93 were males and 23 females, with an average age of $39.6 \pm$
15.0 years, ranging from 18 to 91 years, with a median of 36 years for women and 37 for men. There was a predominance of males ( $n$ $=93 ; 80.17 \%$ ), aged between 31 to 45 years $(n=44.37 ; 93 \%)$, mulatto ethnicity $(n=72$; $62.07 \%)$, incomplete basic education $(n=42$; $36.21 \%)$, with origin of urban area $(n=107$; $92.24 \%)$. The majority of patients lives alone $(n=89 ; 76.72 \%)$, has religious belief $(n=84$; $72.41 \%)$, has not returned to work and/or study ( $n=60 ; 51.72 \%$ ), and was among the lowest socioeconomic levels ( $n=60 ; 51.72 \%)$.

The clinical characteristics of the studied population are shown in Table 1 . Concerning the time of hospitalization, the coefficient of variation was $89.94 \%$, revealing a great level of dispersion for this variable. The same occurred with the time since injury, whose median was ten months, with a coefficient of variation also with great level of dispersion (143.75\%).

Table 1

Distribution of the clinical characteristics of victims of traumatic brain injury undergoing neurosurgery

\begin{tabular}{lcc}
\hline Characteristic & Mean $\pm S D$ & Variation \\
\hline Time of hospitalization (days) & $17.9 \pm 16.1$ & 2 a 101 \\
Time since injury (months) & $20.8 \pm 29.9$ & 1 a 204 \\
\hline & $n$ & $\%$ \\
\hline Mechanism of injury & 48 & 41.38 \\
Traffic accidents & 30 & 25.86 \\
Falls & 23 & 19.83 \\
Violences & 15 & 12.93 \\
Others & & \\
Type of traumatic brain injury (Severity) & 49 & 42.24 \\
Minor & 22 & 18.97 \\
Moderate & 36 & 31.03 \\
Severe & 9 & 7.76 \\
Ignored & & \\
Neurosurgery & 49 & 42.24 \\
Hematoma drainage (subgaleal, AEDH* ASDH $\dagger$ ) & 30 & 25.86 \\
Decompressive craniectomy & 19 & 16.38 \\
Depressed cranial fracture surgery & 18 & 15.52 \\
Others & & \\
Sequelae & 100 & 86.21 \\
Yes & 16 & 13.79 \\
No & & \\
\hline
\end{tabular}




\begin{tabular}{lll}
\hline Type of locomotion & 77 & 66.38 \\
Walks without difficulty & 39 & 33.62 \\
Walks with difficulty & \\
\hline
\end{tabular}

*AEDH: acute extradural hematoma; $\uparrow$ ASDH: acute subdural hematoma.

Regarding the assessment of QOL, the first step in the data analysis consisted of calculating the Cronbach's alpha coefficient, which was $91.93 \%$, meaning a good internal consistency. From the domains of the WHOQOL-Bref, summary and dispersion measures were obtained (Table 2). The highest mean was the general QOL (60.02), while the physical domain had the lowest mean (42.33). Concerning the coefficients of variation, one must note that the domain with the lowest variability is the environment $(27.98 \%)$ and that with the greatest variability is the physical (45.26\%).

After evaluating the medians, one can observe that the median for the social domain is higher than the upper limit of the confidence interval $(M e=58.33)$. It must be considered that the highest concentration for this domain approximates the median. Regarding the other domains, the median is not out of the confidence interval. Thus, the mean was not compromised.

Table 2

Scores obtained by the WHOQOL-Bref in the domains and general QOL of TBI victims undergoing neurosurgery

\begin{tabular}{lcccccc}
\hline Domains & Mean (CI 95\%) & SD & Median & $\begin{array}{c}\text { Coefficient of } \\
\text { Variation (\%) }\end{array}$ & Minimum & Maximum \\
\hline Physical & $42.33(38.81-45.86)$ & 19.16 & 42.86 & 45.26 & 0.00 & 89.29 \\
Psychological & $46.62(43.22-50.03)$ & 18.52 & 47.91 & 39.72 & 0.00 & 91.67 \\
Social & $52.44(48.17-56.72)$ & 23.24 & 58.33 & 44.31 & 0.00 & 100.00 \\
Environment & $46.07(43.7-48.44)$ & 12.89 & 43.75 & 27.98 & 15.63 & 84.38 \\
${ }^{*}$ General QOL & $60.02(55.56-64.48)$ & 24.24 & 56.25 & 40.38 & 18.75 & 93.75 \\
\hline
\end{tabular}

${ }^{*}$ Quality of Life

The correlations between the domains of the WHOQOL-Bref with the quantitative variables time of hospitalization (in days), time since injury (in months) and age of the individuals (in complete years; Table 3) were calculated. After the hypothesis tests to explain the correlations, the following variables obtained statistical significance: age and social domain
$(-0.24 ; p=0.008)$; age and environment domain $(-0.22 ; p=0.017)$; time since injury and physical domain $(-0.19 ; p=0.035)$; time since injury and general quality of life $(-0.20$; $p=0.029)$. All correlations were negative. The variable time of hospitalization did not obtain statistically significant correlations for any of the domains.

\section{Table 3}

Correlation of quantitative variables with the domains of the WHOQOL-Bref according to age, time of hospitalization, time since injury, and the domains

\begin{tabular}{lccccc}
\hline & Physical & Psychological & Social & Environment & General QOL \\
\hline Age & -0.10 & -0.02 & $-0.24^{*}$ & $-0.22^{*}$ & -0.12 \\
Time of hospitalization & -0.02 & -0.14 & -0.06 & -0.06 & 0.01 \\
Time since Injury & $-0.19^{*}$ & -0.10 & -0.13 & -0.14 & $-0.20^{*}$ \\
\hline
\end{tabular}

*Statistically significant correlations according to the Pearson Test. 
The qualitative variables were also associated with the WHOQOL-Bref (Table 4). It was found that those living with their family present higher scores in the social domain $(p=0.026)$ than those who live alone. Concerning the social adjustment, people who, work, or does both have higher scores in the physical and psychological health domains than individuals who do not practice any of these actions $(p=$ 0.027; $p=0.052$, respectively).
Those who walk without difficulty obtained higher scores for the physical domain when compared to those who walk with difficulty $(p=0.035)$. People belonging to the socioeconomic strata of the middle class or higher present better scores than the poorest in the following aspects: psychological $(p=0.012)$, social $(p=0.043)$, and environment $(p=0.01)$. The other variables manifested no statistically significant differences.

Table 4

Comparison of QOL according to the WHOQOL-Bref with the qualitative variables that describe the sociodemographic profile of TBI victims undergoing neurosurgery

\begin{tabular}{|c|c|c|c|c|c|}
\hline & $\begin{array}{c}\text { Physical } \\
\text { Mean } \pm S D\end{array}$ & $\begin{array}{l}\text { Psychological } \\
\text { Mean } \pm S D\end{array}$ & $\begin{array}{c}\text { Social } \\
\text { Mean } \pm S D\end{array}$ & $\begin{array}{l}\text { Environment } \\
\text { Mean } \pm S D\end{array}$ & $\begin{array}{c}\text { General QOL } \\
\text { Mean } \pm S D\end{array}$ \\
\hline \multicolumn{6}{|l|}{ Gender } \\
\hline Male & $41.21 \pm 18.06$ & $46.24 \pm 17.01$ & $51.17 \pm 22,94$ & $45.5 \pm 12.44$ & $58.8 \pm 23.21$ \\
\hline Female & $46.89 \pm 22.98$ & $48.19 \pm 24.06$ & $57.61 \pm 24,22$ & $48.37 \pm 14.65$ & $64.95 \pm 28.06$ \\
\hline$p$-value & 0.197 & 0.336 & 0.144 & 0.331 & 0.215 \\
\hline \multicolumn{6}{|l|}{ Locomotion } \\
\hline With difficulty & $37.36 \pm 16.20$ & $45.41 \pm 16.24$ & $54.06 \pm 19.58$ & $47.76 \pm 10.94$ & $58.17 \pm 21.56$ \\
\hline Without difficulty & $44.85 \pm 20.13$ & $47.24 \pm 19.64$ & $51.62 \pm 24.96$ & $45.21 \pm 13.76$ & $60.96 \pm 25.57$ \\
\hline$p$-value & $0.035^{*}$ & 0.622 & 0.800 & 0.287 & 0.467 \\
\hline \multicolumn{6}{|l|}{ Cohabitation } \\
\hline Alone & $38.19 \pm 15.25$ & $47.76 \pm 10.71$ & $42.31 \pm 18.15$ & $45.92 \pm 9.41$ & $51.44 \pm 14.01$ \\
\hline Family & $42.86 \pm 19.60$ & $46.48 \pm 19.31$ & $53.72 \pm 23.56$ & $46.09 \pm 13.30$ & $61.1 \pm 25.08$ \\
\hline$p$-value & 0.683 & 1 & $0.026^{*}$ & 0.944 & 0.143 \\
\hline \multicolumn{6}{|l|}{ Social adjustment } \\
\hline None & $38.16 \pm 18.17$ & $42.5 \pm 18.83$ & $50.14 \pm 21.94$ & $43.7 \pm 11.94$ & $57.08 \pm 24.01$ \\
\hline Studies/Works & $46.81 \pm 19.34$ & $51.04 \pm 17.27$ & $54.91 \pm 24.5$ & $48.61 \pm 13.48$ & $63,17 \pm 24.30$ \\
\hline$p$-value & $0.027^{*}$ & $0.052^{*}$ & 0.295 & 0.141 & 0.184 \\
\hline \multicolumn{6}{|l|}{ Socioeconomic strata } \\
\hline$<$ middle class & $41.05 \pm 19.00$ & $44.59 \pm 18.85$ & $50.38 \pm 23.77$ & $44.36 \pm 12.75$ & $58.98 \pm 24.89$ \\
\hline$\geq$ middle class & $46.18 \pm 19.47$ & $52.73 \pm 16.30$ & $58.62 \pm 20.71$ & $51.19 \pm 12.11$ & $63.15 \pm 22.31$ \\
\hline$p$-value & 0.245 & $0.012^{*}$ & $0.043^{*}$ & $0.01^{*}$ & 0.511 \\
\hline
\end{tabular}

*Statistically significant differences according to the Mann-Whitney test.

\section{Discussion}

Some characteristics of the individuals in this study follow the worldwide epidemiological pattern of TBI victims, which is composed of young male adults from an urban area, victims of traffic accidents and falls (Monteiro et al., 2016; Santos et al., 2013; Weber et al.,
2016). The clinical profile is also similar to that found in similar studies, with a mean time of hospitalization of approximately a week and the predominance of minor TBI, followed by severe TBI, according to the GCS (Alves et al., 2009; Blennow et al., 2016).

Regarding the application of the WHOQOL-Bref, there is no cut-off-point in the lit- 
erature that classifies the obtained percentages. The physical domain had the lowest value, as occurred in another study (Alves et al., 2009). It should be noted that this domain has the highest coefficient of variation, which shows that there is greater variability in the evaluation of the individuals about this domain.

The negative values of the correlation coefficients indicate that there is an association between an increase in age and a lower assessment of QOL. This can be explained by the fact that the older patients consider that changes in their health arise from the aging process and not from TBI (Weber et al., 2016). This study, unlike the study of Weber et al (2016), observed that patients with a more advanced age showed a tendency towards a worse assessment of QOL, leading to a reduction of scores, namely, of the physical domain, not only related to the age itself, meaning that these results are relevant because they generate subsidies to develop activities with patients in this age range who have suffered traumatic brain injuries. This group is considered to be vulnerable, whose QOL can benefit from special approaches to integral care since its inception (Alves et al., 2009).

Concerning the time since injury, it was found that the negative values of the correlation coefficients showed that the increase in time is associated with a lower assessment of the physical domain and the general quality of life. Other studies show stability in recovery six months after injury (Alves et al., 2009; Weber et al., 2016). The measurement of the impact of injury is particularly challenging due to the wide variation in the types and their severity. To describe the pattern of recovery or residual inability of patients with brain injury over time, all the dimensions of functioning are relevant (Scholten et al., 2015).

The study of the incidence, severity, and duration of the functional consequences of injuries is necessary to make valid estimates of the years lived with disability resulting from this type of aggravation. Some studies show that the majority of victims reach their highest level of functional ability and favorable results relating to the return to productivity in up to 6 months. However, a significant part of the victims manifests improvements until 1 year after the TBI (Vieira et al., 2013). A study which described the QOL of victims of traumatic brain injury
6 months after the incident found that the return to productive activity was the factor that most closely related to the QOL (Vieira et al., 2013). This study highlights a factor of limitation the great variation between the times since injury among patients, which implies the possibility of different QOL assessments since it is a cross-sectional study that projects the reality of the research moment.

Patients who walk without difficulty showed better QOL in the physical domain. Researches on traumatic brain injury and its cognitive implications in QOL concluded that physical independence and competence for the implementation of daily life activities contribute to a better perception of QOL. A similar result occurred in a study that assessed the cognitive, functional, and psychosocial outcome in patients with severe TBI (Sinha et al., 2013). It was also found that there is a significant difference in QOL in the social domain, meaning that it was greater for patients living with their families. Thus, being married or living with someone positively influences the perceptions of QOL for TBI victims (O'Reilly, Wilson, \& Peters, 2017; Vieira et al., 2013).

Regarding social adjustment, this research observed that those who study and/or work have a better QOL in the physical and psychological domains, a result compatible with other studies (Ruet et al., 2017; Weber et al., 2016). Factors that interfere in the maintenance of employment, for instance, fatigue, anxiety, difficulty in concentrating, irritability, inability in managing emotions, and difficulty to participate in group activities may arise from traumatic brain injury, which may justify the results of this study.

The literature presents evidence of an increase in the probability of returning to employment in the first two years after the injury, but this value drops in subsequent years, which translates into a decrease in the return to long-term employment (Grauwmeijer, Heijenbrok-Kal, Haitsma, \& Ribbers, 2017). The return to work also covers aspects related to monthly income. It can be argued that the QOL was better for people of the middle class or above, in the psychological, social, and environment domains. Financial resources are aspects that interfere with the satisfaction with life and can affect greatly the recovery of TBI victims (Ruet et al., 2017). 
The limitations of this study refer to the characteristics of the type of TBI and associated injuries, which only considered brain injuries in the evaluation of the injury's severity, without considering other comorbidities. Also, the Glasgow Coma Scale is only used for the service in question. Another limitation was the absence and/or access to an efficient network of psychosocial support after hospital discharge, which may have influenced the assessment of QOL by participants.

\section{Conclusion}

The neurosurgical victims of TBI showed reduced QOL in the physical domain. It was also found that individuals who walk without difficulty, live with their families, study and/ or work, and have higher socioeconomic levels showed a more satisfactory perception of QOL. Moreover, this study noted that the elderly participants consider that changes in their QOL arise from the traumatic event and not only from age, what makes these results relevant to the planning of health policies focused on this age group.

The results of this study provide subsidies to plan and organize the neuro-injury care and rehabilitation programs. These programs should address not only the physical limitations, but also promote the vocational rehabilitation so that the victim can return to studying/work sooner, strengthen the social life, and explore the mental health so that health teams can achieve the challenge of restoring life with the highest quality possible.

\section{References}

Almeida, C. E., Sousa Filho, J. L., Dourado, J. C., Gontijo, P. A. Dellaretti, M. A., \& Costa, B. S. (2016). Traumatic brain injury epidemiology in Brazil. World Neurosurgery, 87, 540-547. doi:10.1016/j. wneu.2015.10.020.

Alves, A. L., Salim, F. M., Martinez, E. Z., Passos, A. D., Carlo. M. M., \& Scarpelini, S. (2009). Quality of life in trauma victims six months after hospital discharge. Revista de Saúde Pública, 43(1), 154-160. doi:10.1590/S0034-89102009000100020.

Blennow, K., Brody, D. L., Kochanek, P. M., Levin,
H., McKee, A., Ribbers, G. M., Yaffe, K., \& Zetterberg, H. (2016). Traumatic brain injuries. Nature Reviews Disease Primers, 17(2), 16084. doi:10.1038/ nrdp.2016.84.

Cárdenas, S. F., \& Pons, L. S. (2012). The usage of the Cronbach Coefficient alpha in the analysis of the written instruments. Revista Médica Electrónica, 34(1). Retrieved from http://scielo.sld.cu/pdf/rme/v34n1/ spu01112.pdf

Contador, J. L., \& Senne, E. L. (2016). Non-parametric tests for small samples of categorized variables: A study. Gestão \& Produção, 23(3), 588-599. doi: 10.1590/0104-530x357-15.

Fleck, M. P., Louzada, S., Xavier, M., Chachamovich, E., Vieira, G., Santos, L., \& Pinzon, V. (2000). Application of the Portuguese version of the abbreviated instrument of quality life WHOQOL-bref. Revista de Saúde Pública, 34(2), 178-183. doi: 10.1590/S003489102000000200012.

Grauwmeijer, E., Heijenbrok-Kal, M. H., Haitsma, I. K., \& Ribbers, G. M. (2017). Employment outcome ten years after moderate to severe traumatic brain injury: A prospective Cohort Study. Journal of Neurotrauma, 34(17), 2575-2581. doi: 10.1089/neu.2016.4846.

Hinkle, D. E., Wiersma, W., \& Jurs, S. G. (1998). Applied statistics for the behavioral sciences (4th ed.). Boston, MA: Houghton Mifflin.

Monteiro, L. F., Frasson, M. Z., Wrsesinski, A., Bardini, A. V., Lin, J., \& Fernandes, A. F. (2016). Caracterização dos pacientes com traumatismo cranioencefálico grave admitidos em um hospital terciário. Arquivos Catarinenses de Medicina, 45(3), 2-16. Retrieved from http://www.acm.org.br/acm/seer/index.php/ arquivos/article/view/107/98.

O’Reilly, K., Wilson, N., \& Peters K. (2017). Narrative literature review: Health, activity and participation issues for women following traumatic brain injury. Disability and Rehabilitation, 6, 1-12. doi:10.1080/ 09638288.2017.1334838.

Oliveira, D. M., Pereira, C. U., \& Freitas, Z. M. (2014). Scales for evaluating the level of consciousness in trauma brain injury and their relevance to nursing practices. Arquivos Brasileiros de Neurocirurgia, 33(1), 22-32. Retrieved from http://files.bvs.br/upload/S/0103-5355/2014/v33n1/a4284.pdf

Peeters, W., van den Brande, R., Polinder, S., Brazinova, A., Steyerberg, E. W., Lingsma, H. F., \& Maas, A. I. (2015). Epidemiology of traumatic brain injury in Europe. Acta Neurochirurgica, 157(10),1683-96. doi:10.1007/s00701-015-2512-7.

Rodrigues, R. A., Robazzi, M. L., Erdmann, A. L., Fernandes, J. D., Barros, A. L., \& Ramos, F. R. (2015). 
Doctoral theses from nursing postgraduate programs in Brazil and their association with the Millennium Development Goals. Revista Latino-Americana de Enfermagem, 23(3), 395-403. doi:10.1590/01041169.0667.2565.

Ruet, A., Jourdan, C., Bayen, E., Darnoux, E., Sahridj, D., Ghout, I., ... Azouvi, P. (2017). Employment outcome four years after a severe traumatic brain injury: Results of the Paris severe traumatic brain injury study. Disability and Rehabilitation, 18,1-8. doi:10.1080/09638288.2017.1327992.

Santos, F., Casagranda, L. P., Lange, C., Farias, J. C., Pereira, P. M., Jardim, V. M. R., \& Torres, A. A. (2013). Traumatic brain injury: Causes and profile of victims attended to at an emergency health clinic in Pelotas, Rio Grande do Sul, Brazil. Revista Mineira de Enfermagem, 17(4), 882-887. doi:10.5935/14152762.20130064.

Scholten, A. C., Haagsma, J. A., Andriessen, T. M., Vos, P. E., Steyerberg, E. W., van Beeck, E. F., \& Polinder, S. (2015). Health-related quality of life after mild, moderate and severe traumatic brain injury: Patterns and predictors of suboptimal functioning during the first year after injury. Injury, 46(4), 616-624. doi: 10.1016/j.injury.2014.10.064.

Sinha, S., Gunawat, P., Nehra, A., \& Sharma, B. S. (2013). Cognitive, functional, and psychosocial outcome after severe traumatic brain injury: A cross-sectional study at a tertiary care trauma center. Neurology India, 61(5), 501-506. doi:10.4103/0028-3886.121920

Vieira, R. C., Hora, E. C., Oliveira, D. V., Ribeiro, M. C., \& Sousa, R. M. (2013). Quality of life of victims of traumatic brain injury six months after the trauma. Revista Latino-Americana de Enfermagem, 21(4), 868-75. doi:10.1590/S0104-11692013000400006

Weber, K. T., Guimarães, V. A., Pontes Neto, O. M., Leite, J. P., Takayanagui, O. M., \& Pontelli, T. E. (2016). Predictors of quality of life after moderate to severe traumatic brain injury. Arquivos de Neuro-Psiquiatria, 74(5), 409-415. doi:10.1590/0004-282X2016005.

World Health Organization. (1997). Whoqol: Measuring quality of life. Geneva: Author. 
